\title{
Learning-Induced Expression of Meningeal Ependymin mRNA and Demonstration of Ependymin in Neurons and Glial Cells
}

\author{
Stefan Rother, Rupert Schmidt, *Wolfgang Brysch, and †Karl-Hermann Schlingensiepen \\ AK Neurochemie, Zoologisches Institut, Biozentrum der J. W. Goethe-Universität, Frankfurt am Main; *Biognostik GmbH, \\ Göttingen; and $\uparrow$ Abteilung Neurobiologie, Max-Planck-Institut für biophysikalische Chemie, Göttingen, Germany
}

\begin{abstract}
The turnover of a CNS-specific cell adhesion glycoprotein, ependymin, has earlier been found to increase during periods of neuronal plasticity. Here, ependymin mRNA expression was analyzed by semiquantitative in situ hybridization in goldfish. Learning of an active avoidance response resulted in a significant increase in ependymin mRNA expression $20 \mathrm{~min}$ to $4 \mathrm{~h}$ after acquisition of the task. In contrast, yoked control animals that were exposed to the same numbers of conditioned and unconditioned stimuli in a random, unpaired manner exhibited a strong down-regulation of ependymin mRNA. Hybridization signals were also increased by injection of anti-ependymin antiserum into brain ventricles. Ependymin mRNA was exclusively localized to reticularshaped fibroblasts of the inner endomeningeal cell layer. Immunoelectron microscopic investigation, however, revealed ependymin also in distinct neuronal and glial cell populations in which no ependymin mRNA had been detected. Uptake of meningeal protein factors into glial and neuronal cells may therefore be of functional importance for plastic adaptations of the CNS. Key Words: Memory and learning - mRNA expression-Cell adhesion molecules-Fibroblasts-Meninges-Stress.

J. Neurochem. 65, 1456-1464 (1995).
\end{abstract}

Formation of long-term memory is associated with structural modifications in synaptic connectivities and requires de novo protein synthesis (Flexner et al., 1962) and protein glycosylation (Matthies, 1989; Rose, 1991; Scholey et al., 1993). However, up to now only a few distinct proteins have been identified displaying an enhanced turnover after the acquisition of a new behavior (Hydén and Lange, 1970; Shashoua, 1976; Schmidt, 1987). One of these proteins was called ependymin according to its first immunohistochemical localization in the ependymal region of the teleost brain (Benowitz and Shashoua, 1977). Ependymin is a secretory, CNS-specific glycoprotein displaying calcium and zinc binding properties (Schmidt and Makiola, 1991; Ganss and Hoffmann, 1993). It is functionally related to cell adhesion molecules. Ependymin forms homo- and heterodimers (Schmidt and Shashoua, 1981) and carries the HNK-1 cell adhesion carbohydrate (Shashoua et al., 1986; Schmidt and Schachner, 1994), and, moreover, it supports axonal growth in vitro (J. T. Schmidt et al., 1991).

Cell adhesion molecules play an important role in developmental differentiation and appear to be also involved in behaviorally induced adaptations of the CNS (Breen and Regan, 1988; Persohn et al., 1989; Edelman et al., 1990; Schmidt and Makiola, 1991; Schubert, 1991; Bailey and Kandel, 1993; Scholey et al., 1993). A similar function has been assigned to ependymin (Schmidt and Makiola, 1991), because inactivation of the secreted protein by injection of specific antibodies proved its direct involvement in the consolidation of plastic neural adaptations, such as the activity-driven sharpening of receptive fields during regeneration of the retinotectal projection (Schmidt and Shashoua, 1988) and operant (Shashoua and Moore, 1978; Schmidt, 1987) and classical (Piront and Schmidt, 1988; Shashoua and Hesse, 1989) conditioning in goldfish.

To investigate whether ependymin mRNA expression is triggered by conditioned learning, goldfish were trained in a shuttle-box and killed at various intervals after acquisition of the task. Brain sections were processed for in situ hybridization and compared with untrained and yoked controls. Preliminary accounts of part of this work have been presented as abstracts (Rother et al., 1990; R. Schmidt et al., 1991).

Received January 11, 1995; revised manuscript received April 5, 1995; accepted April 6, 1995.

Address correspondence and reprint requests to Dr. R. Schmidt at AK Neurochemie, Zoologisches Institut, Biozentrum der J. W. Goethe-Universität, Marie-Curie-Strasse 9, D-60439 Frankfurt am Main, Germany.

Abbreviations used: SSC, saline-sodium citrate; TBS, Tris-buffered saline. 


\section{MATERIALS AND METHODS}

\section{Chemicals}

The silver enhancement kit was bought from Biocell (Cardiff, U.K.); $\left[\alpha-{ }^{32} \mathrm{P}\right] \mathrm{dATP}(222 \mathrm{TBq} / \mathrm{mmol})$ and $\alpha-{ }^{35} \mathrm{~S}-$ dATP ( $55 \mathrm{TBq} / \mathrm{mmol}$ ) from Du Pont de Nemour (Dreieich, Germany); biotin-11-dUTP, biotin-conjugated alkaline phosphatase, 5-bromo-4-chloro-3-indolyl phosphate, 2,2'di-p-nitrophenyl-5,5'-diphenyl-3,3'-(3,3'-dimethoxy-4,4'diphenylene)-ditetrazolium chloride, and streptavidin from GibcoBRL (Paisley, Scotland); terminal transferase (from calf thymus) from Pharmacia (Freiburg, Germany); and Denhardt's solution, DNA (denatured, from salmon testes), fluorescein isothiocyanate- and gold-coupled goat anti-rabbit IgG antibodies, poly(dA), and Tween 20 from Sigma (Deisenhofen, Germany).

\section{Goldfish conditioning}

Goldfish (Carassius auratus) were kept at $20^{\circ} \mathrm{C}$ at a constant 12:12-h light/dark cycle for at least 6 weeks before the experiments. Fish were trained in a shuttle-box to cross a hurdle and avoid mild electric shocks (unconditioned stimulus) administered $20 \mathrm{~s}$ after a light signal (conditioned stimulus) until they achieved a learning criterion of $80 \%$ correct avoidance responses as described previously (Piront and Schmidt, 1988; see also Schmidt et al., 1995a). At various intervals $(10 \mathrm{~min}-8 \mathrm{~h})$ after acquisition of the task, goldfish were anesthetized by cooling for $5 \mathrm{~min}$ in ice water and killed by decapitation. Brains were quickly removed from the skull and frozen in liquid nitrogen. Brains were cut to $15-\mu$ m-thick sections on a cryostat and prepared for in situ hybridization. Results from conditioned fish were compared with three control groups: (a) untrained goldfish; (b) overtrained goldfish, which were repeatedly exposed to the shuttle-box paradigm and after three training sessions performed the task almost without mistakes and without any need to learn further or improve the avoidance response; and (c) yoked controls that underwent a pseudoconditioning in which they were exposed to the same (average) number of light signals and electroshock punishments as learning fish but in a randomized, unpaired fashion. Clearly these goldfish were "stressed," but the protocol did not enable them to form a timed association between the administered stimuli.

\section{Oligodeoxynucleotide probes}

The oligodeoxynucleotide 5'-TCGCTTTGGAGTCATAACTGAACTCTCCAG-3', complementary to ependymin mRNA (Königstorfer et al., 1989), was synthesized using standard methods (Adams et al., 1983; Engels and Uhlmann, 1988 ). Over 200,000 sequences (GenBank and EMBL) were screened to largely exclude for the most part the possibility of false-positive hybridizations. The probe was labeled by 3 '-extension (Maniatis et al., 1982) using terminal transferase (from calf thymus) and $\left[\alpha-{ }^{32} \mathrm{P}\right] \mathrm{dATP}(222 \mathrm{TBq} /$ mmol) to obtain a specific activity of $300 \mathrm{TBq} / \mathrm{mmol}$ of oligodeoxynucleotide after purification by molecular sieve chromatography. The corresponding sense counterpart of the probe served as a negative control. To obtain higher resolution, in some experiments oligodeoxynucleotides were labeled with $\alpha{ }^{35}$ S-dATP ( $55 \mathrm{TBq} / \mathrm{mmol}$ ) or with biotin-11dUTP, using the same enzyme and labeling protocol (purification by precipitation in ethanol).

\section{In situ hybridization}

In situ hybridization was performed as described previously (Herms et al., 1993, 1994). In brief, coronal cryostat-cut sections were transferred to sterilized microscopic slides (covered with $0.5 \%$ gelatin), fixed in $4 \%$ paraformal-

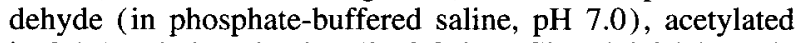
in $0.1 \mathrm{M}$ triethanolamine (in $0.9 \% \mathrm{NaCl}$ and $0.25 \%$ acetic anhydride, $\mathrm{pH} 8.0$ ), dehydrated and delipidated in ethanol $(70-100 \%)$ and chloroform, and incubated for $2 \mathrm{~h}$ in prehybridization buffer composed of $4 \times$ saline-sodium citrate (SSC; $600 \mathrm{~m} M \mathrm{NaCl}$ and $60 \mathrm{~m} M$ sodium citrate, $\mathrm{pH} 7.0$ ) and $5 \times$ Denhardt's solution ( $1 \mathrm{mg}$ of Ficoll, $1 \mathrm{mg}$ of polyvinylpyrrolidone, and $1 \mathrm{mg}$ of bovine serum albumin $/ \mathrm{ml}$ ) in $50 \%$ deionized formamide containing $50 \mathrm{~m} M$ sodium phosphate ( $\mathrm{pH} 6.5$ ), $1 \mathrm{mM}$ sodium pyrophosphate, $120 \mu \mathrm{g}$ of heparin, $100 \mu \mathrm{g}$ of denatured DNA (from salmon testes), $100 \mu \mathrm{g}$ of poly (dA), and $100 \mu \mathrm{g}$ of bakers yeast $/ \mathrm{ml}$. Sections were subsequently reacted at $35^{\circ} \mathrm{C}$ for $24 \mathrm{~h}$ with $50 \mu \mathrm{l}$ of the same buffer containing $10 \mathrm{kBq}$ of the deoxynucleotide probe, washed in $1 \times \mathrm{SSC}$ at $22^{\circ} \mathrm{C}$ and in $0.1 \times \mathrm{SSC}$ at $40^{\circ} \mathrm{C}$ for $1 \mathrm{~h}$ each, dehydrated in $300 \mathrm{mM} \mathrm{NH} \mathrm{N}_{4} \mathrm{Cl}$ in $70 \%$ ethanol and in $300 \mathrm{mM} \mathrm{NH} \mathrm{mH}_{4} \mathrm{Cl}$ in $90 \%$ ethanol $(20 \mathrm{~s}$ each $)$, dried, and exposed to x-ray film (Hyperfilm MP; Amersham, Buckinghamshire, U.K.) for 12 h. Sections hybridized with ${ }^{35}$ S-oligodeoxynucleotides were covered with photoemulsion (K5; Ilford, Neu-Isenburg, Germany) and exposed for 14 days.

Biotin-labeled sections were washed in $1 \times \mathrm{SSC} /$ formamide (1:1), $1 \times \mathrm{SSC}$, and $0.1 \times \mathrm{SSC}$ at $37^{\circ} \mathrm{C}$ for $30 \mathrm{~min}$ each and saturated with $5 \%$ bovine serum albumin in Trisbuffered saline [TBS; $1 M \mathrm{NaCl}, 0.1 M$ Tris- $\mathrm{HCl}$ ( $\mathrm{pH} 7.5$ ), and $2 \mathrm{mM} \mathrm{MgCl} 2$ containing $0.005 \%$ Tween 20 ]. For visualization, sections were incubated with streptavidin $(2 \mu \mathrm{g} / \mathrm{ml}$ of TBS) and biotin-conjugated alkaline phosphatase for $1 \mathrm{~h}$ each, washed in TBS, and reacted for $1-4 \mathrm{~h}$ (in the dark) with a mixture of $4.4 \mu 1$ of $2,2^{\prime}$-di- $p$-nitrophenyl-5, $5^{\prime}$-diphenyl-3,3'-(3,3'-dimethoxy-4,4' -diphenylene) ditetrazolium chloride $(75 \mathrm{mg} / \mathrm{ml}$ of $70 \%$ dimethylformamide $)$ and $3.3 \mu \mathrm{l}$ of 5-bromo-4-chloro-3-indolyl phosphate $(50 \mathrm{mg} / \mathrm{ml}$ of $70 \%$ dimethylformamide) in $1 \mathrm{ml}$ of a solution containing $0.1 \mathrm{M}$ $\mathrm{NaCl}, 0.1 M$ Tris-HCl (pH 9.5), and $5 \mathrm{mM} \mathrm{MgCl}_{2}$. The reaction was terminated with a solution containing $5 \mathrm{~m} M$ EDTA in $20 \mathrm{mM}$ Tris-HCl ( $\mathrm{pH} 7.5$ ). Sections were then dehydrated and embedded.

\section{Quantification of hybridization signals}

The gray level of ${ }^{32} \mathrm{P}$ autoradiographs on $\mathrm{x}$-ray films was digitized with a $C C D$ video camera (Kappa Instruments, Gleichen, Germany ) connected to a Macintosh IIfx computer (Apple, Cupertino, CA, U.S.A.) via a Quick-Capture frame grabber (Data Translation, Marlboro, MA, U.S.A.) and evaluated using the public-domain software Image (version 1.28; National Institutes of Health, Bethesda, MD, U.S.A.). The intensity of the autoradiographic signal was measured by calculating the area under the curve of the signal intensity plot from perpendicular bars ( $2 \mathrm{~mm}$ long and $100 \mu \mathrm{m}$ wide) drawn across the hybridization signal at six different positions: at angles of $30^{\circ}, 60^{\circ}, 135^{\circ}, 225^{\circ}, 300^{\circ}$, and $330^{\circ}$, where the dorsal crossing of a median vertical line through the section with the hybridization signal is $0^{\circ}$. Statistically significant differences from $\mathbf{n}$ ( see Results) animals were established using a two-tailed $t$ test. 

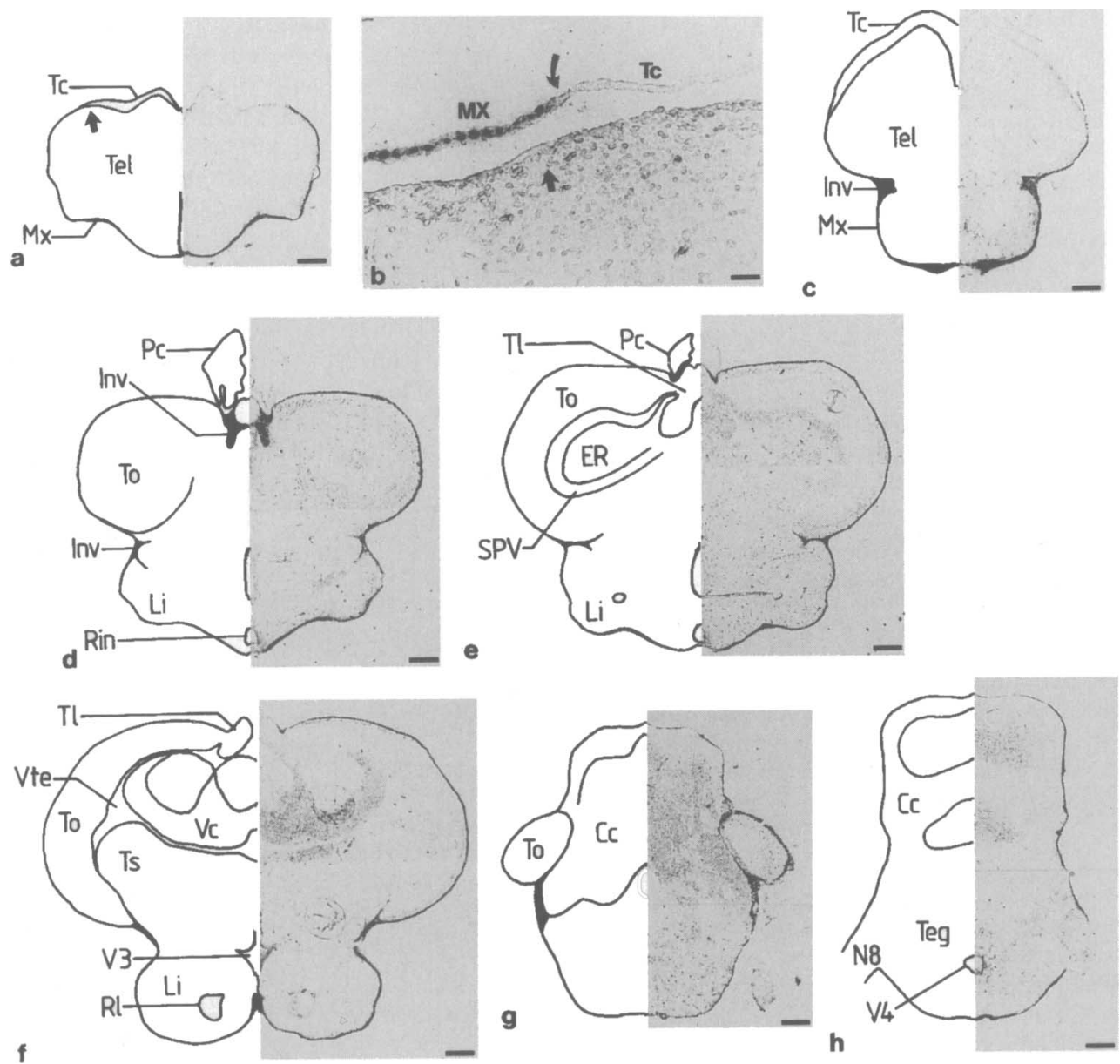

FIG. 1. Coronal sections of goldfish brain hybridized with ${ }^{35} \mathrm{~S}$-labeled oligodeoxynucleotide probes against ependymin mRNA. In situ hybridization in all sections is confined to the distinct layer of the leptomeninx surrounding the brain. Only unspecific labeling is observed in the neuronal parenchyma. a: "Rostral" telencephalon (Tel), partly covered by meninx (MX), partly by tela chorioidea (Tc). An enlargement appears in (b). Arrows mark the sharp termination of the endomeninx with labeled cells. Bar $=30 \mu \mathrm{m}$. c-h: Frontal sections from caudal telencephalon to caudal cerebellum. Cc, corpus cerebelli; ER, ependymal region; Inv, meningeal invagination; Li, lobus inferior; N8, eighth brain nerve; Pc, plexus chorioideus; Rin, recessus infundibularis; RI, recessus lateralis; SPV, stratum periventriculare; Teg, tegmentum; TI, torus longitudinalis; To, tectum opticum; Ts, torus semicircularis; Vc, valvula cerebelli; Vte, ventriculus tectalis; V3 and V4, third and fourth brain ventricle, respectively. Bar $=0.3 \mathrm{~mm}$ in (a) and (c-h).

\section{Immunohistochemistry}

Immunohistochemistry was performed as described previously (Schmidt, 1989; Schmidt et al., 1990): For light microscopy, goldfish brains were fixed by perfusion with Bouin-Debosq solution, cut on a cryostat to $10-\mu$ m-thick sections, and incubated for $16 \mathrm{~h}$ with rabbit anti-ependymin serum raised against deglycosylated ependymin (1:80 dilution) at $4^{\circ} \mathrm{C}$. No cross-reactivities with other antigens are known of this antiserum. The corresponding preimmune serum failed to produce a signal. Antigen-antibody complexes were visualized by fluorescein isothiocyanate-coupled goat anti-rabbit IgG antibodies. For preembedding immunoelectron microscopy, brains were fixed by perfusion and immersion with an isotonic phosphate-buffered saline containing $4 \%$ paraformaldehyde, $0.2 \%$ glutardialdehyde, and $0.2 \%$ picric acid, cut to $100-\mu \mathrm{m}$-thick sections on a Vibratome, and incubated for $36 \mathrm{~h}$ with the antiserum (1:200 dilution) at $4^{\circ} \mathrm{C}$. Antigen-antibody complexes were visualized by gold- coupled goat anti-rabbit IgG antibodies and contrasted by silver enhancement. Sections were then postfixed in $2 \%$ glutardialdehyde and $1 \%$ osmium tetroxide, contrasted with $1 \%$ uranyl acetate in $70 \%$ ethanol, dehydrated, embedded in Epon, cut to 60 -nm-thick sections, and analyzed on a Zeiss EM 902 electron microscope.

\section{RESULTS}

\section{Localization of ependymin mRNA}

In situ hybridizations using ${ }^{35} \mathrm{~S}$-labeled oligodeoxynucleotide probes localized ependymin mRNA in all brain regions exclusively to the endomeninx and meningeal invaginations (Fig. 1). No staining was observed using radiolabeled control oligodeoxynucleotides (sense probes; data not shown). No ependymin mRNA was detected in the tela chorioidea (Fig. 1a- 
FIG. 2. In situ hybridizations with a biotinylated oligodeoxynucleotide probe against ependymin mRNA. a: Schematic representation of goldfish optic tectum and diencephalon. Positions of the enlarged segments shown in the other panels are indicated. RI, recessus lateralis; Ts, torus semicircularis. b: Individual cells (arrowheads) are stained in the meninx covering the stratum marginale (SM) of the dorsal tectum. PMF, perimeningeal fluid. Bar $=30$ $\mu \mathrm{m}$. c: Arrowheads point to ependymin-synthesizing cells of fibroblast morphology in the ventral part of the inferior lobe (Li; hypothalamus) that surround leptomeningeal blood vessels $(\mathrm{Bg})$. The broken line delineates the position of the basement membrane below the meninx. Bar $=20 \mu \mathrm{m}$. d: Meningeal cell population in an invagination between the optic tectum (To) and the inferior lobe in close proximity to a larger blood vessel. Most cells exhibit cytoplasmic staining, whereas cell nuclei are unstained (arrowheads). Bar $=30 \mu \mathrm{m}$. e: Intense hybridization signal at a meningeal invagination (arrows) of the valvula cerebelli (Vc). There is no ependymin synthesis detectable in the parenchyma of the optic tectum or torus longitudinalis $(\mathrm{TI})$. Bar $=150 \mu \mathrm{m}$.
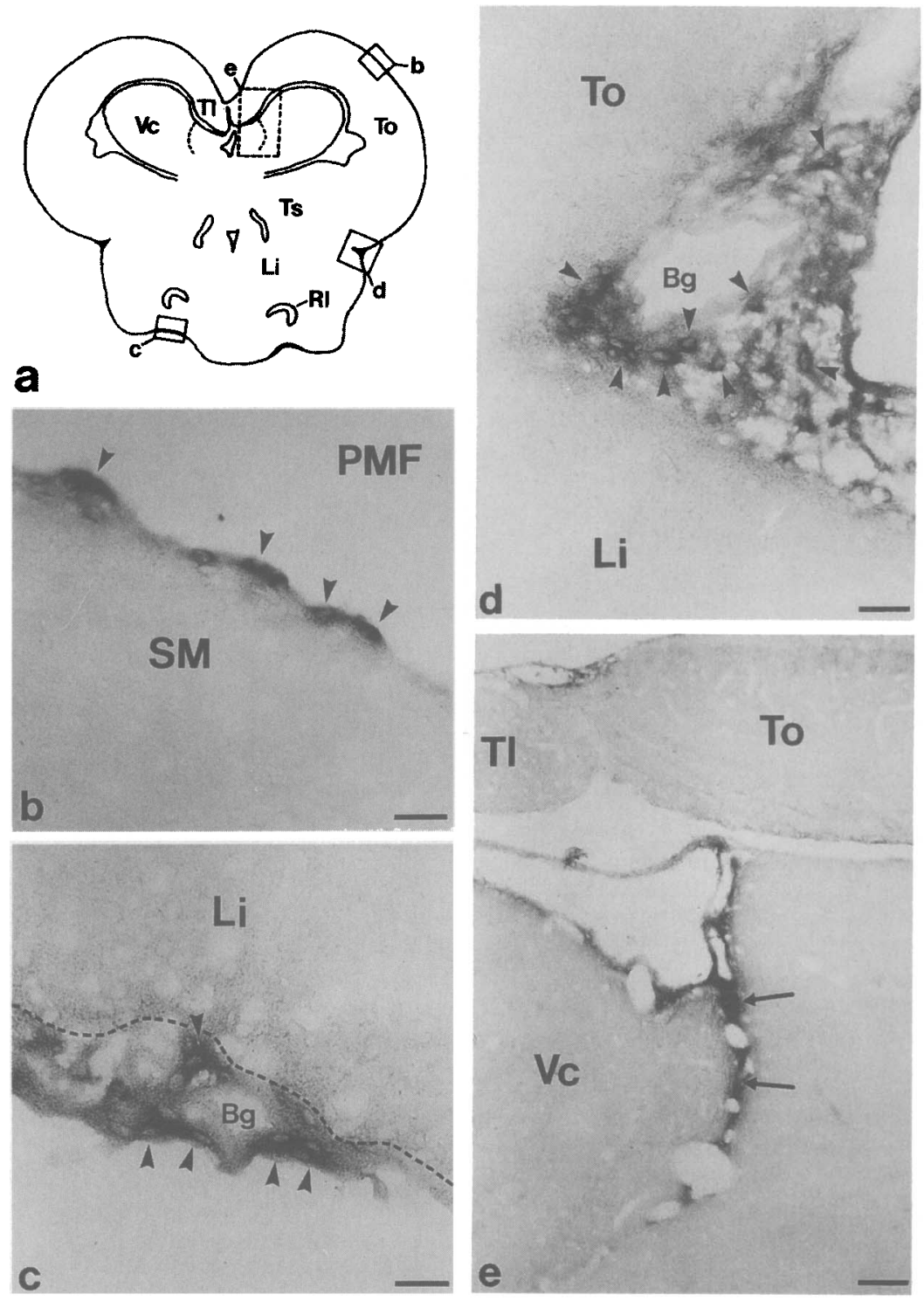

c), the plexus chorioidei, and the perineurium of brain nerves (see, e.g., N8 in Fig. 1h). The periventricular cell layer and the zona ependyma (SPV and ER in Fig. 1e), which are known to contain cells reacting with anti-ependymin antisera (Benowitz and Shashoua, 1977; Schmidt, 1989), did not hybridize with the radiolabeled oligodeoxynucleotide.

In situ hybridization with nonradioactive oligodeoxynucleotide probes enabled cellular localization of ependymin synthesis (Fig. 2). Biotinylated probes stained the large fibroblasts of the leptomeninx, morphologically identified as the "reticular-shaped cells", described in the inner endomeningeal layer of the goldfish optic tectum by Momose et al. (1988) (see also Fig. 5), which appear arranged as a single layer on coronal sections (Figs. $1 \mathrm{~b}$ and $2 \mathrm{~b}$ ). These fibroblasts reach a particularly high cell density around blood vessels and in meningeal invaginations (Fig. 2d-e).

\section{Increase in ependymin mRNA content after conditioning}

Goldfish were trained on an active avoidance task in a shuttle-box until they reached a learning criterion of eight correct responses during 10 consecutive trials. One hour after acquisition of the task, all conditioned animals $(n=4)$ displayed a pronounced increase in ependymin mRNA expression as compared with untrained fish ( $n=4$; Fig. 3). Overtrained goldfish did not learn the task in the final training session, as they remembered the avoidance response from preceding exposures to the shuttle-box. They displayed moderate or no increase in the hybridization signal. Yoked con- 


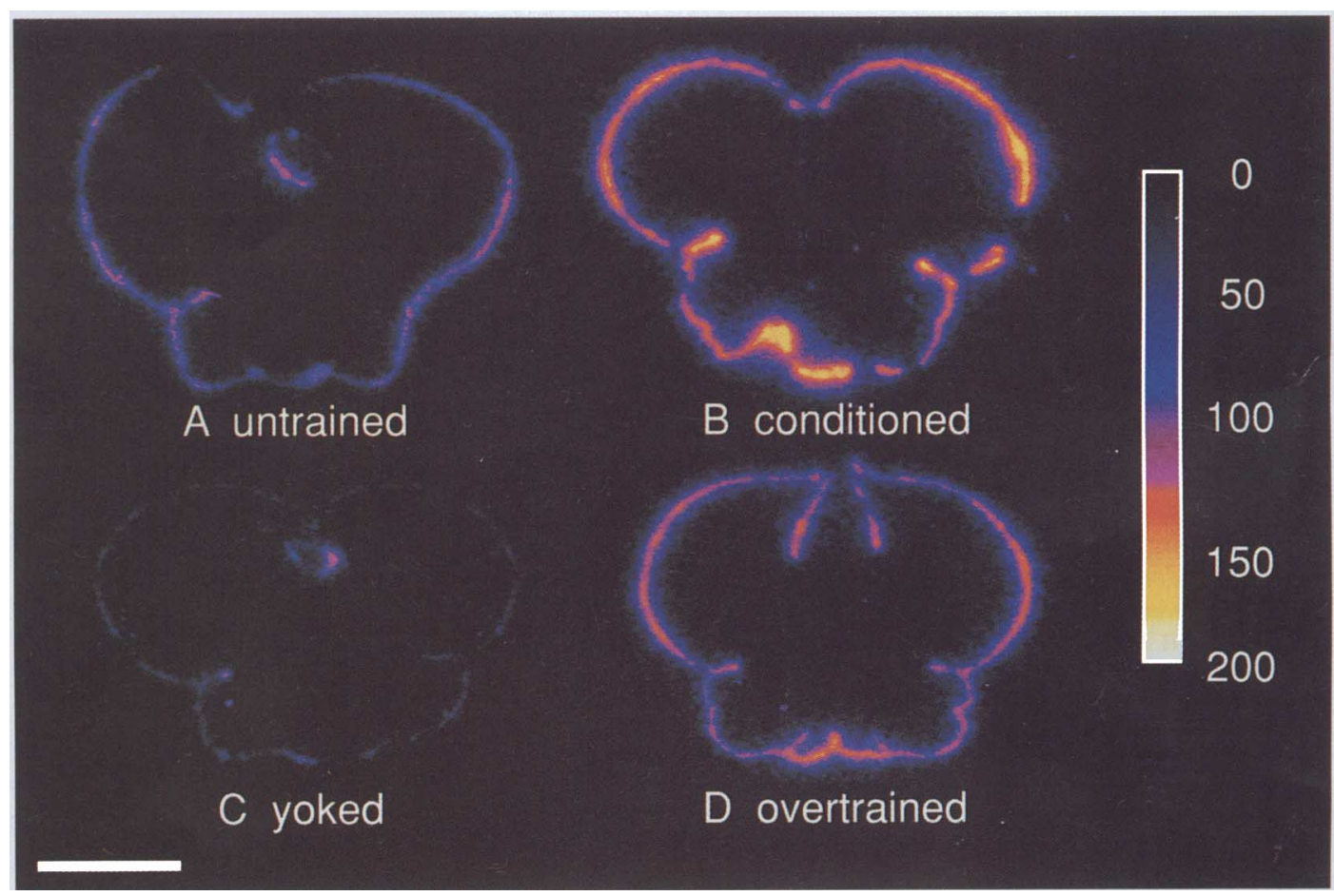

FIG. 3. False color representation of autoradiographs from coronal sections of goldfish brain hybridized with a $3^{\prime}-\left[\alpha^{-}{ }^{32} \mathrm{P}\right] \mathrm{dATP}-\mathrm{labeled}$ oligodeoxynucleotide probe complementary to ependymin mRNA. A: Untrained goldfish. B: Conditioned fish trained to criterion on the avoidance task and killed $1 \mathrm{~h}$ later. C: Yoked controls received conditioned and unconditioned stimuli in a randomized, unpaired fashion ("stress") $1 \mathrm{~h}$ before they were killed. D: Overtrained animals had undergone three training sessions on different days and were killed $1 \mathrm{~h}$ after the last session. Scale shows the relative intensity of the autoradiographic signal. Bar $=2 \mathrm{~mm}$.

trol fish that were exposed to unpaired light and electroshock stimuli exhibited no increase, but rather a depression in ependymin mRNA (Fig. 3).

The time course of ependymin mRNA expression is shown in Fig. 4. For each animal, three coronal sections through the mes- and diencencephalon were evaluated, and six measurements were taken on each autoradiograph (four from the tectum and two from the inferior lobe; compare Materials and Methods). Eighteen measurements were thus averaged per fish and treated as one independent value for statistical analysis. In conditioned goldfish, the content of ependymin mRNA increased within $10 \mathrm{~min}$, reaching a first peak at $20 \mathrm{~min}(211 \%$ of untrained controls, $p<0.01)$. After a transient decrease a second maximum occurred at $2 \mathrm{~h}(245 \%$ of untrained controls, $p<0.05)$, and values declined to the control level after $8 \mathrm{~h}$. The signal at $40 \mathrm{~min}$ is different from that at $20 \min (p<0.05)$, but the signal at $1 \mathrm{~h}$ is not significantly different from that at $2 \mathrm{~h}$. If values obtained at $40 \mathrm{~min}$ and $1 \mathrm{~h}$ are pooled, however, they are different from those at $2 \mathrm{~h}$ $(p<0.05)$. A transient but less pronounced increase at $20 \mathrm{~min}$ was also observed in yoked goldfish $(140 \%$ of untrained controls; Fig. 4). Afterward, however, the signal declined below control values $(57 \%$ at $1 \mathrm{~h}, p$ $<0.05$ ) and returned to the baseline level at $8 \mathrm{~h}$.

To investigate whether a decrease of the extracellu-

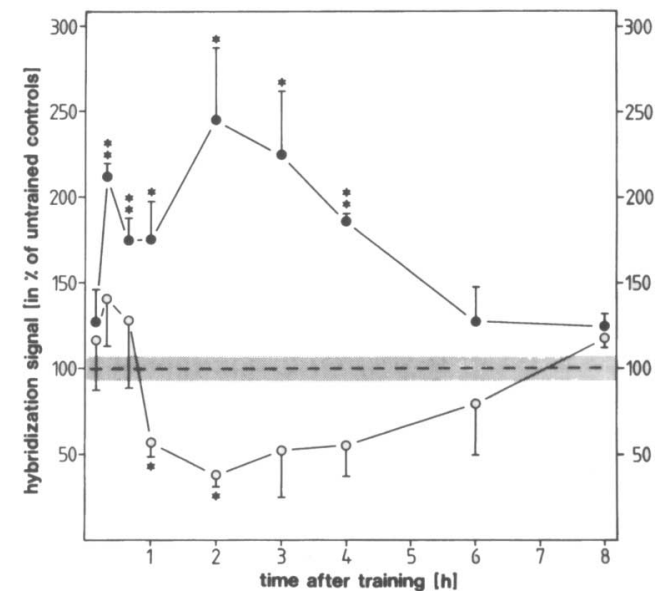

FIG. 4. Time course of ependymin mRNA expression in conditioned $(\bullet)$ and yoked $(O)$ goldfish after completion of the shuttlebox experiments. Intensity of autoradiographic hybridization signals was evaluated by an image analysis system and is expressed as a percentage of values of untrained controls $(100 \%$ $=$ broken line, SEM $=$ shaded area). Data are average \pm SEM (bars) signal of three or four animals. Significant differences from control values are indicated: ${ }^{\star} p<0.05,{ }^{\star \star} p<0.01$. 
FIG. 5. Immunohistochemical demonstration of ependymin-containing cells in the brain of untrained goldfish. A: Light micrograph of a coronal section of the goldfish optic tectum displays the endomeninx (MX), marginal layer $(\mathrm{ML})$, optic layer (OL), and the superficial gray and plexiform layer (SGL). Note the intense immunofluorescence of the endomeninx and of a type I neuron (arrow) with its characteristic apical dendrite. B: Electron micrograph taken from the goldfish endomeninx. Ependymin immunoreactivity is specifically localized within the cytoplasm and processes of reticular-shaped cells (RC) of the inner endomeningeal layer (IL). The marginal layer $(\mathrm{ML})$ of the underlying neural parenchyma is separated by a basal lamina (arrowheads) and ependymin-positive endfeet of radial glial cells (EF). FC, flattened cells of the outer endomeningeal layer. Bar $=2.33 \mu \mathrm{m}$. C: Higher magnification of a process $(P)$ of a reticular-shaped fibroblast. Arrowheads point to the basal lamina. Immunogold particles $(5 \mathrm{~nm}$; small arrows) are specifically enriched at the rough endoplasmic reticulum ( $r E R$; see enlargement). Bar $=0.35 \mu \mathrm{m}$. D: A labeled dendrite (D) of a type I neuron as it passes through the optic layer (OL), which comprises many myelinated optic fibers (OF). Note that cross-sectioned optic fibers are free of label. Bar $=2.33$ $\mu \mathrm{m}$. Sections shown in B and D were treated with silver enhancer; the section shown in $\mathrm{C}$ was not.

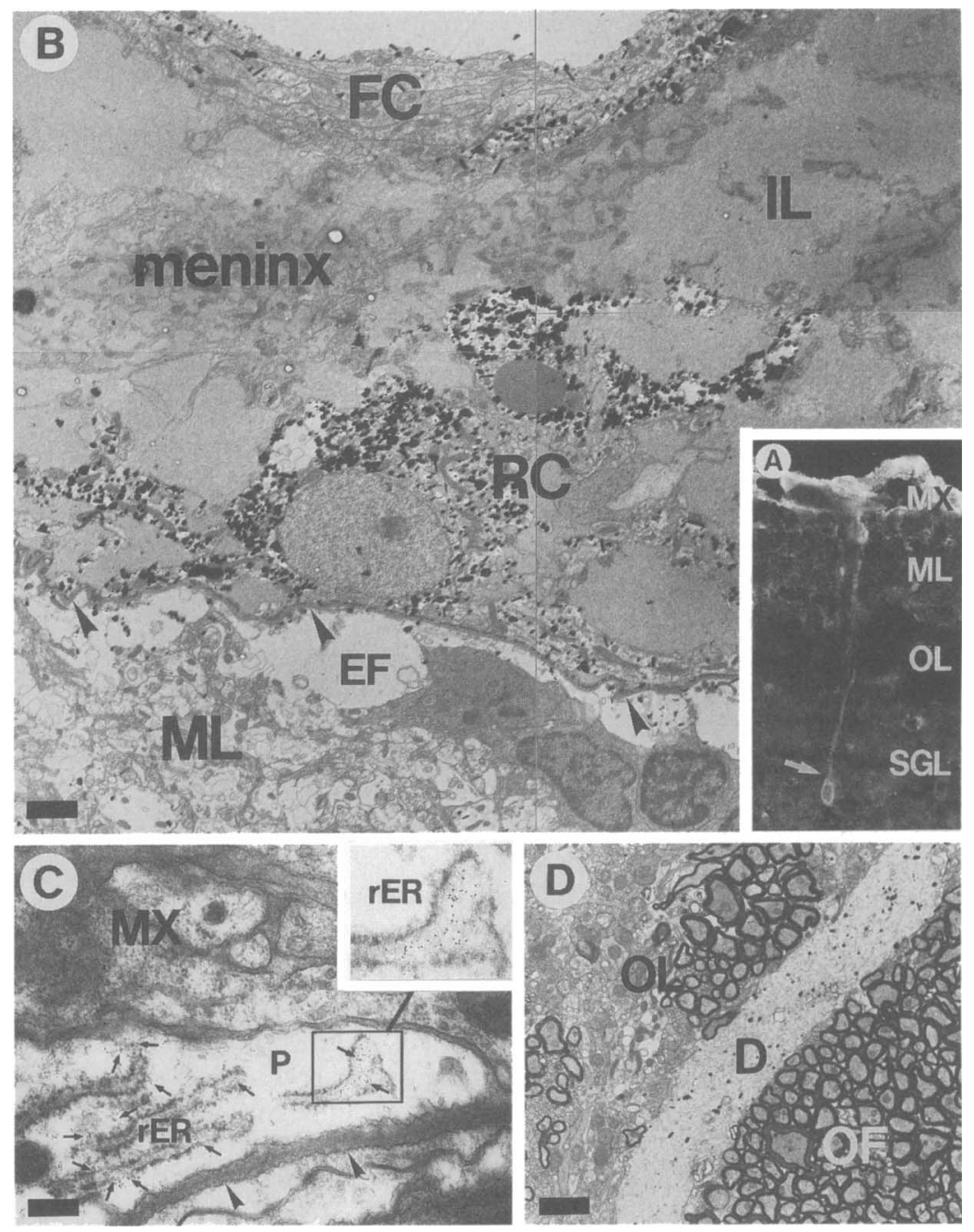

lar ependymin concentration provides a negative feedback signal for ependymin mRNA transcription in meningeal fibroblasts, $10 \mu \mathrm{l}$ of undiluted anti-ependymin antiserum was injected into the brain ventricles of untrained goldfish. Experiments revealed a significant increase $(p<0.01)$ in meningeal mRNA expression by $28 \pm 2 \%($ mean $\pm \mathrm{SEM}, \mathrm{n}=4) 3 \mathrm{~h}$ after injection as compared with controls $(n=4)$ that had received the same amount of an isotonic $\mathrm{NaCl}$ solution. There was also a trend toward higher mRNA expression in $\mathrm{NaCl}$-injected fish as compared with uninjected controls. However, this increase, which may have been induced by dilution of ependymin in the extracellular brain fluid, was not significant.

\section{Immunohistochemical localization of ependymin}

In accordance with the in situ hybridizations, strong ependymin immunoreactivity was detected in the reticular-shaped fibroblasts of the endomeninx (Fig. 5B). These fibroblasts are densely packed with Golgi apparatus, rough endoplasmic reticulum, and multivesicular bodies, as is characteristic of secretory cells. Ependymin immunoreactivity was specifically localized at the rough endoplasmic reticulum (Fig. 5C), confirming that the reticular-shaped fibroblasts represent the main or the only site of ependymin synthesis and secretion in goldfish brain.

Light and electron microscopic observations also revealed ependymin immunoreactivity in dendrites and cell bodies of type I neurons in the superficial gray and plexiform layer of the optic tectum (Fig. 5A and D) in addition to its localization in ependymal (data not shown) and radial glial (Fig. 5B) cells.

\section{DISCUSSION}

Learning-induced de novo protein synthesis is predominantly assigned to neuronal cells. Here, we describe the rapid and specific increase in expression of mRNA for the CNS-specific cell adhesion molecule ependymin in nonneuronal, meningeal cells by active avoidance conditioning. Ependymin mRNA expres- 
sion was restricted to a distinct population of fibroblasts in the inner endomeningeal cell layer of goldfish brain, confirming earlier studies on ependymin mRNA expression in goldfish (Königstorfer et al., 1990; Rother et al., 1990) and trout (Schwarz et al., 1993). After active avoidance conditioning expression of ependymin mRNA was markedly enhanced. A subsequent study (Schmidt et al., 1995a) will analyze by antisense intervention whether de novo synthesis of ependymin molecules is a prerequisite for long-term consolidation of the newly acquired avoidance response.

The time course of ependymin mRNA expression after learning is in agreement with investigations on ependymin turnover (Shashoua, 1976; Schmidt, 1989) and steady-state concentrations (Schmidt, 1987; Shashoua and Hesse, 1989). These studies revealed maximally elevated concentrations of ependymin in cytoplasmic fractions at $5 \mathrm{~h}$ after acquisition, followed by secretion (maximum in the extracellular brain fluid at $9 \mathrm{~h}$ ). The increase in ependymin mRNA content may be caused by induction of the ependymin gene or by posttranscriptional mechanisms regulating mRNA stability. The time course of ependymin mRNA expression in conditioned animals with two relative maxima (at $20 \mathrm{~min}$ and $2 \mathrm{~h}$ ) is reminiscent of the two phases of glycoprotein synthesis after learning in mammals (Matthies, 1989) and birds (Freeman et al., 1995).

A less pronounced increase of ependymin mRNA content at $20 \mathrm{~min}$ was also observed in yoked goldfish (Fig. 4), similar to the accumulation of c-fos mRNA in rat hippocampus after both acquisition of a brightness discrimination task and pseudoconditioning (Tischmeyer et al., 1990). Furthermore, there was an increase in overtrained fish at $20 \mathrm{~min}$ but no significant difference from controls at later time points (data not shown). The first peak of ependymin mRNA expression may therefore not be specific for associative learning, but rather be induced by arousal or stress reactions. Quantitative analyses of stress hormone levels during active and even passive avoidance tasks in mammals indicated a strong stress reaction during training, in particular in good learners (Dunn et al., 1986; Matthies, 1989). To what extent endocrine responses of the hypothalamic-pituitary-adrenocortical axis, elicited by the training situation, contribute to the mechanisms of learning and memory formation, is still an open question (McGaugh, 1989; McEwen et al., 1991), but recent experiments suggest functional involvement of mineralocorticoid and glucocorticoid receptors in brain in the processes of acquisition and memory consolidation, respectively (Oitzl and De Kloet, 1992; Sandi and Rose, 1994). It has to be considered therefore that early constituents of the arousal reaction and stress-associated hormonal factors may trigger the first peak of ependymin mRNA expression (Schmidt et al., 1995b) and prime the CNS for plastic adaptation. Long-lasting elevation in ependymin
mRNA expression, however, was specific for conditioned animals and not observed in yoked controls. Instead, yoked fish displayed a decline even below baseline values of untrained controls within $1 \mathrm{~h}$.

These results raise the questions of how meningeal cells distinguish between different training procedures, i.e., conditioned versus pseudoconditioned or yoked, and what provides the signal for long-lasting elevated mRNA expression after learning. Ependymin is secreted into the extracellular brain fluid and contributes $15 \%$ to its total protein contents (Schmidt, 1987). Earlier experiments revealed a temporary decrease of this extracellular ependymin pool by 8 and $19 \%$ up to $4 \mathrm{~h}$ after operant (Schmidt, 1987) and classical (Shashoua and Hesse, 1989) conditioning, respectively. Experiments with injected anti-ependymin antisera reported here indicate that such a depletion of the extracellular ependymin pool may provide a negative regulatory feedback signal for the expression of ependymin mRNA in meningeal fibroblasts. A regulation of ependymin transcription via the extracellular concentration of the translation product would also explain the decrease of mRNA expression below baseline levels in yoked controls: Because ependymin pools are not depleted by stress procedures (Schmidt, 1987; Shashoua and Hesse, 1989), the transiently enhanced mRNA synthesis is expected to result in an extracellular surplus of ependymin, which may then serve as a negative feedback signal to meningeal cells. Because no innervation of the meningeal fibroblasts has been described, it appears reasonable that ependymin transcription is regulated by humoral factors, i.e., hormones and the soluble translation product.

The transient decrease in extracellular ependymin content after conditioning may be caused by its polymerization in the vicinity of activated synapses, where the extracellular $\mathrm{Ca}^{2+}$ concentration is markedly reduced (Morris et al., 1986; Shashoua, 1988/89; Schmidt, 1989; Schmidt and Makiola, 1991). Alternatively, it may result from uptake into neurons, such as tectal type I neurons, which receive synaptic input from the optic nerve and the longitudinal torus (Meek, 1981) and may therefore participate in the integration of visual and vestibular excitations during shuttle-box learning. Indeed, our light and electron microscopic observations revealed ependymin immunoreactivity in dendrites and cell bodies of type I neurons and in radial glial cells, i.e., in cells where no ependymin mRNA was detected (Fig. 5) (compare also Schmidt, 1989; Schmidt et al., 1990).

Our results obtained by semiquantitative in situ hybridization and immunohistochemistry point toward a crucial role of the meninx and meninx-derived proteins in plasticity of the teleost CNS. Similar mechanisms may operate in mammals. Recent morphological studies on the developing rodent brain revealed involvement of meningeal fibroblasts and possibly of diffusible meningeal proteins in glial and neuronal lamina- 
tion of the cerebellum and the dentate gyrus (Sievers et al., 1986; Hartmann et al., 1992). We conclude that interactions among meningeal, glial, and neuronal cells via secreted protein factors may play a much more prominent role in developmental and behavioral adaptations of the vertebrate CNS than hitherto anticipated.

Acknowledgment: We are indebted to Ingrid Klinger and Susanne Gathmann for technical assistance and to the Deutsche Forschungsgemeinschaft for financial support (grants Schm 478/4-4 and Gr 650/5-2).

\section{REFERENCES}

Adams S. P., Kavka K. S., Wykes E. J., Holder S. B., and Galluppi G. R. (1983) Hindered dialkylamino nucleoside phosphite reagents in the synthesis of two 51-mers. J. Am. Chem. Soc. 105, $661-663$.

Bailey C. H. and Kandel E. R. (1993) Structural changes accompanying memory storage. Annu. Rev. Physiol. 55, 397-426.

Benowitz L. I. and Shashoua V. E. (1977) Localization of a brain protein metabolically linked with behavioral plasticity in the goldfish. Brain Res. 136, 227-242.

Breen K. C. and Regan C. M. (1988) Differentiation-dependent sialylation of individual neural cell adhesion molecule polypeptides during postnatal development. J. Neurochem. 50, 712 716

Dunn A. J., Elfrin K. L., and Berridge C. W. (1986) Changes in plasma corticosterone and cerebral biogenic amines and their catabolites during training and testing of mice in passive avoidance behavior. Behav. Neural Biol. 46, 410-423.

Edelman G. M., Cunningham B. A., and Thiery J. P., eds (1990) Morphoregulatory Molecules. Wiley, New York.

Engels J. and Uhlmann E. (1988) Gene synthesis, in Advances in Biochemical Engineering/Biotechnology, Vol. 37 (Fiechter A., ed), pp. 73-127. Springer-Verlag, Berlin.

Flexner J. B., Flexner L. B., Stellar E., de la Haba G., and Roberts R. B. (1962) Inhibition of protein synthesis in brain and learning and memory following puromycin. J. Neurochem. 9, 595605

Freeman F. M., Rose S. P. R., and Scholey A. B. (1995) Two time windows of anisomycin-induced amnesia for passive avoidance training in the day-old chick. Neurobiol. Learn. Mem. (in press ).

Ganss B. and Hoffmann W. (1993) Calcium binding to sialic acids and its effect on the conformation of ependymins. Eur. J. Biochem. 217, 275-280.

Hartmann D., Sievers J., Pehlemann F. W., and Berry M. (1992) Destruction of meningeal cells over the cerebral hemisphere of newborn hamsters prevents the formation of the infrapyramidal blade of the dentate gyrus. J. Comp. Neurol. 320, 33-61.

Herms J., Zurmöhle U., Brysch W., and Schlingensiepen K.-H. (1993) $\mathrm{Ca}^{2+} /$ calmodulin protein kinase and protein kinase $\mathrm{C}$ expression during development of rat hippocampus. $\mathrm{Dev}$. Neurosci. 15, 410-416.

Herms J., Zurmöhle U., Schlingensiepen R., Brysch W., and Schlingensiepen K.-H. (1994) Developmental expression of the transcription factor zif 268 in rat brain. Neurosci. Lett. 165, $171-$ 174.

Hydén H. and Lange P. W. (1970) Brain-cell protein synthesis specifically related to learning. Proc. Natl. Acad. Sci. USA 65 , 898-904.

Königstorfer A., Sterrer S., Eckerskorn C., Lottspeich F., Schmidt R., and Hoffmann W. (1989) Molecular characterization of an ependymin precursor from goldfish brain. J. Neurochem. $\mathbf{5 2}$, $310-312$.

Königstorfer A., Sterrer S., and Hoffmann W. (1990) Ependymins are expressed in the meninx of goldfish brain. Cell Tissue Res. 261, 59-64.

Maniatis T., Fritsch E. F., and Sambrook J. (1982) Molecular Cloning. A Laboratory Manual. Cold Spring Harbor Laboratory, Cold Spring Harbor, New York.

Matthies H. (1989) Neurobiological aspects of learning and memory. Annu. Rev. Psychol. 40, 381-404.

McEwen B. S., Coirini H., Westlind-Danielsson A., Frankfurt M., Gould E., Schumacher M., and Wolley C. (1991) Steroid hormones as mediators of neural plasticity. J. Steroid Biochem. Mol. Biol. 39, 223-232.

McGaugh J. L. (1989) Involvement of hormonal and neuromodulatory systems in the regulation of memory storage. Annu. Rev. Neurosci. 12, 255-287.

Meek J. ( 1981) A Golgi-electron microscopic study of goldfish optic tectum I. Description of afferents, cell types and synapses. $J$. Comp. Neurol. 199, 149-173.

Momose Y., Kohno K., and Ito R. (1988) Ultrastructural study on the meninx of the goldfish brain. J. Comp. Neurol. 270, 327336.

Morris M. E., Ropert N., and Shashoua V. E. (1986) Stimulusevoked changes in extracellular calcium in optic tectum of the goldfish: possible role in neuroplasticity. Ann. NY Acad. Sci. 481, 375-377.

Oitzl M. S. and De Kloet E. R. (1992) Selective corticosteroid antagonists modulate specific aspects of spatial orientation learning. Behav. Neurosci. 106, 62-71.

Persohn E., Pollerberg G. E., and Schachner M. (1989) Immunoelectronmicroscopic localization of the $180 \mathrm{kD}$ component of the neural cell adhesion molecule N-CAM in postsynaptic membranes. J. Comp. Neurol. 288, 92-100.

Piront M.-L. and Schmidt R. (1988) Inhibition of long-term memory formation by anti-ependymin antisera after active shock-avoidance learning in goldfish. Brain Res. 442, 53-62.

Rose S. P. R. (1991) How chicks make memories: the cellular cascade from c-fos to dendritic remodelling. Trends Neurosci. 14, 390-397.

Rother S., Brysch W., Schlingensiepen K.-H., and Schmidt R. (1990) Synthesis and ultrastructural distribution of ependymins in goldfish brain analysed by in situ hybridization and immuno gold labelling. Biol. Chem. Hoppe Seyler 371, 1031.

Sandi C. and Rose S. P. R. (1994) Corticosteroid receptor antagonists are amnestic for passive avoidance learning in day-old chicks. Eur. J. Neurosci. 6, $1292-1297$.

Schmidt J. T. and Shashoua V. E. (1988) Antibodies to ependymin block the sharpening of the regenerating retinotectal projection in goldfish. Brain Res. 446, 269-284.

Schmidt J. T., Schmidt R., Lin W., Jian X., and Stürmer C. A. O. (1991) Ependymin as a substrate for outgrowth of axons from cultured explants of goldfish retina. J. Neurobiol. 22, 40-54.

Schmidt R. (1987) Changes in subcellular distribution of ependymins in goldfish brain induced by learning. J. Neurochem. 48, $1870-1878$.

Schmidt R. (1989) Glycoproteins involved in long-lasting plasticity in the teleost brain, in Progress in Zoology, Vol. 37: Fundamentals of Memory Formation: Neuronal Plasticity and Brain Function (Rahmann H. and Lindauer M., eds), pp. 327-339. Fischer-Verlag, Stuttgart.

Schmidt R. and Makiola E. (1991) Calcium and zinc ion binding properties of goldfish brain ependymin. Life Sci. Adv. (Neurochem.) 10, 161-171

Schmidt R. and Schachner M. (1994) Inhibition of memory consolidation after active shock avoidance conditioning by injection of L2/HNK-1 antibodies into goldfish brain. (Abstr.) J. Neurochem. 63 (Suppl. 1), S61B.

Schmidt R. and Shashoua V. E. (1981) A radioimmunoassay for ependymins $\beta$ and $\gamma$ : two goldfish brain proteins involved in behavioral plasticity. J. Neurochem. 36, 1368-1377.

Schmidt R., Rother S., and Schwerdtfeger W. K. (1990) Glycoproteins of the extracellular matrix mediate plasticity in the CNS, 
in The Forebrain in Nonmammals: New Aspects of Structure and Development (Schwerdtfeger W. K. and Germroth P., eds), pp. 17-28. Springer-Verlag, Berlin.

Schmidt R., Rother S., Schlingensiepen K.-H., and Brysch W. (1991) Rapidly increased expression of ependymin mRNA in goldfish brain after acquisition of an active avoidance behaviour, in Synapse-Transmission-Modulation (Elsner N. and Penzlin H., eds ), pp. 30, 543. Thieme, Stuttgart.

Schmidt R., Brysch W., Rother S., and Schlingensiepen K.-H. (1995a) Inhibition of memory consolidation after active avoidance conditioning by antisense intervention with ependymin gene expression. $J$. Neurochem. 65, 1465-1471.

Schmidt R., Gebke E., and Porrmann R. (1995b) Involvement and regulation of meninx-derived cell adhesion molecules in CNS plasticity. Verh. Dtsch. Zool. Ges. 88.1, 15.

Scholey A. B., Rose S. P. R., Zamani M. R., Bock E., and Schachner M. (1993) A role for the neural cell adhesion molecule in a late, consolidating phase of glycoprotein synthesis six hours following passive avoidance training of the young chick. Neuroscience 55, 499-509.

Schubert D. (1991) The possible role of adhesion in synaptic modification. Trends Neurosci. 14, 127-130.

Schwarz H., Müller-Schmid A., and Hoffmann W. (1993) Ultrastructural localization of ependymins in the endomeninx of the brain of the rainbow trout: possible association with collagen fibrils of the extracellular matrix. Cell Tissue Res. 273, 417425.

Shashoua V. E. (1976) Brain metabolism and the acquisition of new behaviors. I. Evidence for specific changes in the pattern of protein synthesis. Brain Res. 111, 347-364.

Shashoua V. E. (1988/89) The role of ependymin in the development of long lasting synaptic changes. J. Physiol. (Paris) 83, $232-239$.

Shashoua V. E. and Hesse G. (1989) Classical conditioning leads to changes in extracellular concentrations of ependymin in goldfish brain. Brain Res. 484, 333-339.

Shashoua V. E. and Moore M. E. (1978) Effect of antisera to $\beta$ and $\gamma$ goldfish brain proteins on the retention of a newly acquired behavior. Brain Res. 148, 441-449.

Shashoua V. E., Daniel P. F., Moore M. E., and Jungalwala F. B (1986) Demonstration of glucuronic acid on brain glycoproteins which react with $\mathrm{HNK}-1$ antibody. Biochem. Biophys. Res. Commun. 138, 902-909.

Sievers J., Pehlemann F. W., and Berry M. (1986) Influences of meningeal cells on brain development. Naturwissenschaften $\mathbf{7 3}$, $188-194$.

Tischmeyer W., Kaczmarek L., Strauss M., Jork R., and Matthies H. (1990) Accumulation of c-fos mRNA in rat hippocampus during acquisition of a brightness discrimination. Behav. Neural Biol. 54, 165-171. 